\title{
FEATURES OF THE CENOZOIC DEFORMATION PHASES ON CO TO - THANH LAN ISLANDS (QUANG NINH PROVINCE, TONKIN GULF, VIETNAM)
}

\author{
Truong Thanh Phi', Renat Shakirov', Duc Anh Le ${ }^{3}$, Duc Tung Van ${ }^{4}$, Anatoly Obzhirov', \\ Syrbu Nadezhda \\ ${ }^{1}$ Hanoi University of Natural Resources and Environment; \\ ${ }^{2}$ V.I. Il'ichev Pacific Oceanological Institute-FEB RAS; \\ ${ }^{3}$ Institute of Marine Geology and Geophysics-Viet Nam Academy of Science and Technology; \\ ${ }^{4}$ Institute of Geology-Viet Nam Academy of Science and Technology \\ email: ren@poi.dvo.ru \\ Received July 6, 2016
}

\begin{abstract}
The analytical results of over sixty striations on the fault surface, the movement of quartz veins and marked stratigraphy which selected at 18 different survey sites on Co To - Thanh Lan islands (Tonkin Gulf, Northern Vietnam) have indicated that the tectonic activity of this area has 04 mainly compressive phases of E-W, NE-SW, NW-SE, N-S direction and 02 extensive phases of NE-SW and NW-SE direction. Based on the generation (before and after) among overlap striations of the same fault surfaces at survey sites of CT-02, CT-03, CT-05 and TL-04, the tectonic phases with mainly compressive directions are determined: (1) E-W, (2) NE-SW, (3) NW-SE and (4) N-S. These obtained results match with some previous regional studies, but revealed new detail structural features of structural-tectonics pattern on the islands in Tonkin Gulf (Bacbo Gulf). Moreover, in the study area and adjacent area, we have also identified the certain relationship between tectonic faults and the anomalies of methane, helium, high hydrocarbons and carbon dioxide at survey sites along fault zones, continuously further confirms the existence of the faulting. Obtained results allow discussing large scale structural features defined by the Red River Fault Zone and adjacent geo-blocks development. The rotation movements of the blocks, including islands in the Tonkin Gulf (Northern Vietnam) proposed to discuss in the future surveys and considering during the analyses of the field results. Gasgeochemical anomalies prove permeability and activity of some faults in the study area.
\end{abstract}

Key words: Cenozoic, deformation phases, compression, extension phases, tectonics, gas-geochemistry, Tonkin gulf, Vietnam.

\section{INTRODUCTION}

The Co To - Thanh Lan islands are located in the north of the Tonkin Gulf, in the eastern area of Quang Ninh province, Vietnam. The main composition of the sedimentary rocks on these two islands includes: sandstone, siltstone and claystone, which generated in the deep sea environment [13]. The studies of geology in here are conducted from early $[5,7,13,14]$. Initially, since without evidences of geology so the sediments in this area are suggested as the age of Neogen [5]. Until 1972, these sedimentary rocks are determined as the age of Ordovic-Silurian $\left(\mathrm{O}_{3}-\mathrm{S}_{1} c t\right.$ and $\left.\mathrm{O}_{3}-\mathrm{S}_{2} c t\right)$ based on Graptolite fossil by [23]. Then they are continuously confirmed by the other authors $[3,12]$. Some other studies in relation to tectonic activity in this study area are primarily mentioned along the Red River Fault System [3, 8, 10, 15, 21, 24]. However, there is not any study which considered the tectonics and geo-dynamics, respectively, in Co To Thanh Lan area.

The Red River Fault System is proposed as a left-lateral motion and caused by the compression direction of $\mathrm{E}-\mathrm{W}$, during the Oligocene-Miocene period $[8,10,15$, 24], the collision between Indian and Eurasian plates [21] and the right-lateral motion caused by the compression direction of N-S, during the Pliocene-Quaternary period $[8,9,10,24]$. Besides, the other studies along the Cao Bang-Tien Yen (CB-TY) fault zone in the NE of Red River Fault System (Fig. 1) also determined left-lateral mo- 

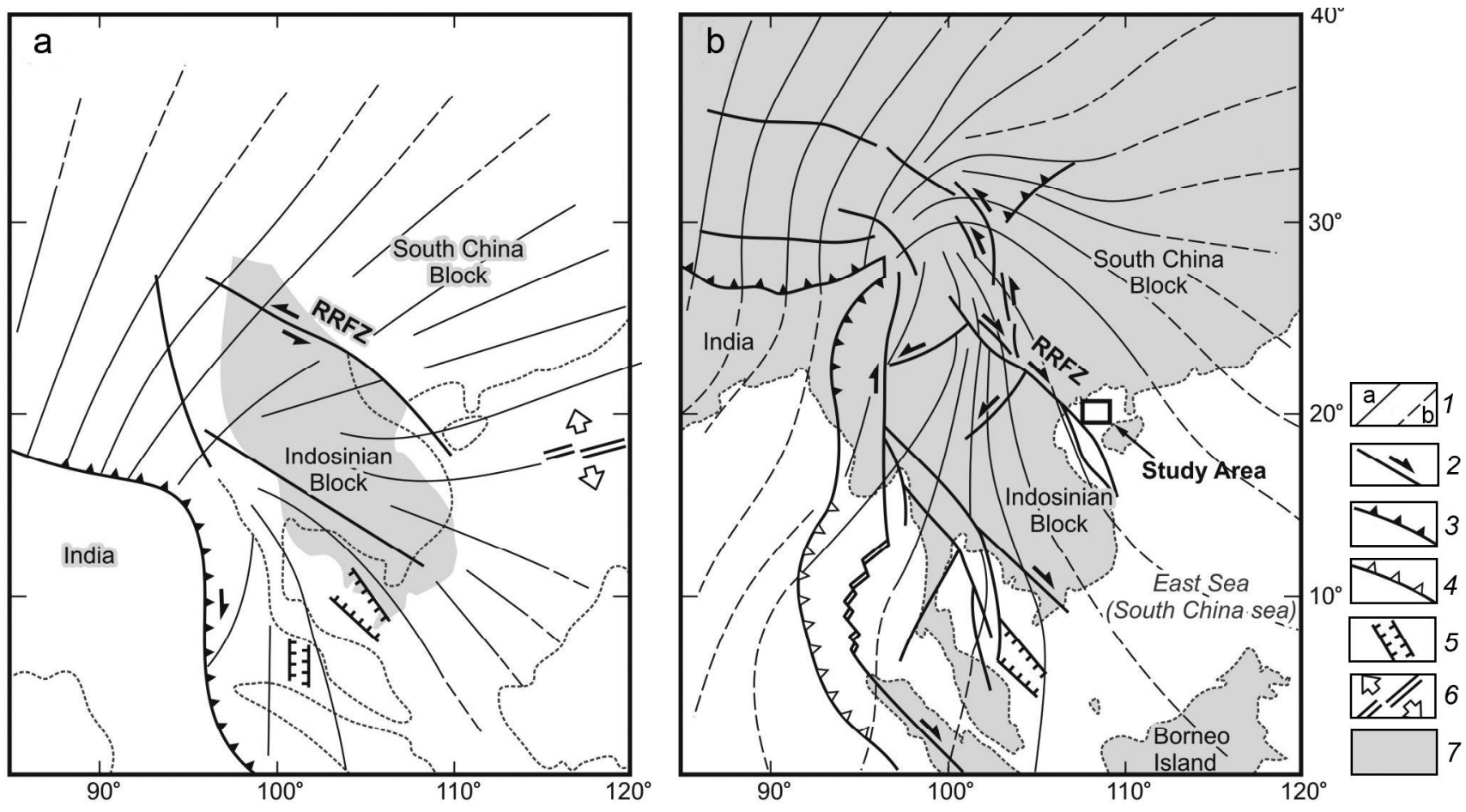

Figure 1. Trajectories of the maximum compressive stress within the Indochina Peninsula from Pliocene to the present time (b) [8] modified from Huchon (1994).

The legend on the map in Figure 1 is described as following: (1) trajectories of the maximum compressive stress is directly related to the Indo-Eurasian plate collision (a) and its far-field effects (b); (2) faults and directions of displacement (arrows); (3) zone of continental collision; (4) subduction zone; (5) extension structures; (6) spreading zones; (7) current position of the land; Red River Fault System (RRFS); Cao Bang - Tien Yen fault (CB-TY).

tion during the Oligocene-Miocene period and right-lateral motion during the Pliocene-Quaternary period [17, 22].

The left-lateral motion of Red River Fault System was the results of India-Eurasia plate collision [21] and it occurred during within $30 \mathrm{Ma}$ to $5.5 \mathrm{Ma}$, corresponding to the Oligocene-Miocene period, from analytical results of the seismic data [18]. The another analytical result of seismic profiles in the north area of the Red River sedimentary basin also identified one phase of left-lateral motion which occurred about before $21 \mathrm{Ma}$ within the Song Lo and Song Chay river fault zone, belong to the Red River Fault System [11]. Besides, the study also indicated one different tectonic activity phase with the NESW compression direction, caused the inversion of NWSE trending fault during 10.5 k.y-5.5 k.y. In addition, analyzing geological structure of Oligocene sedimentary rocks on Bach Long Vi Island also determined three maximum compression phases: E-W, NE-SW and NW-SE during the Cenozoic period [16]. These analytical results have important significance for the tectonic activity phase determination on the Co To - Thanh Lan of this study. Noticeably, we found methane anomalies up to $538 \mathrm{nmo}-$ $1 / 1$, corresponding to hydrogen peaks (154-236 ppm) and high concentrations of helium (13-24 ppm) on Bach Long $\mathrm{Vi}$ island [2]. Those anomalies correlated to asphalt seepage sites and highly likely, linked to compressive tectonic pattern.

Recently, analyzing tributaries of the Red River Fault System from Quaternary alluvial fans, river valley on Landsat and SPOT satellite images, detailed topographical maps and field observation determined right-lateral offsets of stream channels range between 150 and $700 \mathrm{~m}$ [15]. This is the results of the stress field of N-S compression direction; E-W extension direction caused the right lateral strike-slip along the Red River Fault System and, probably, began in the Pliocene time. The tectonic phase also was clearly visible on the Red River Fault System and the Dien Bien Phu fault from the analyses of Landsat and SPOT satellite images [9, 15].

The another analysis also recognized that $\mathrm{Cao}$ Bang - Tien Yen fault which is located in the NE of the Red River Fault System was right lateral strike-slip fault, results from the N-S compression direction using Landsat and SPOT satellite images, aerophotographs and 1:50.000 scale topographic maps [15]. The relation to dextral strike-slip motion of the Red River Fault System in the 
episode of Pliocene-Quaternary also confirmed in study [24]. The result of tectonic-geomorphic studies indicated that the amount of Quaternary dextral offset of the Red River Fault System in Vietnam, calculated from offset and deflection of the tributary valleys of the Red River, ranges between some $400 \mathrm{~m}$ and $5.3 \mathrm{~km}$. The axis of maximum horizontal compression associated with dextral slip of the fault zone was aligned from NNW-SSE to N-S.

Similarly, another study indicated that predominantly sinistral strike slip of Red River Fault System formed as a result of ENE regional compression $\left(80^{\circ}\right)$ during the Oligocene-Miocene period and dextral strike slip of the Red River Fault System formed as a result of NNW regional compression 330-350 $0^{\circ}$ during the Pliocene-Quaternary time [8].

The results of the above listed studies will be the basis to match and verify the determination of tectonic activity phases revealed on original field work and computer interpretation - purpose of the paper.

\section{DATA AND METHODS}

The collection data is carried out at 18 different survey sites on the Co To - Thanh Lan islands, including fracture orientation, striation evidences on the fault surface, movement of quartz veins and marked stratigraphy in Ordovician-Silurian sedimentary rocks $\left(\mathrm{O}_{3}-\mathrm{S}_{1} c t\right.$ and $\mathrm{O}_{3}-\mathrm{S}_{2} c t$ ) of $\mathrm{Co}$ To formations within the square area of Figure 1.

The data collection was conducted using the geocompass equipments to measure the dip direction/dip angle of the fault and striation evidences on the fault surface and the GPS to determine survey location. Striation measurements include it's strike value and slope angle. In which, the strike value is measured following orientation of a vertical plane which contains striation on the fault surface and the slope angle is the inclination of striation with the horizontal plane; fracture orientation is measured, including: dip direction and dip angle of the fault surface; quartz movement is measured, including: dip direction and dip angle of the fault surface and the distance of the quartz vein on two sides of the fault; stratigraphy movement is measured, including: dip direction and dip angle of fault surface and movement distance of the stratigraphy on two sides of the fault. We use the software Faultkin 7 of Allmendinger R. W. to identify stress state, including: Sigma1 $\left(\sigma_{1}\right), \operatorname{Sigma} 2\left(\sigma_{2}\right), \operatorname{Sigma} 3\left(\sigma_{3}\right)$, to be base for determining deformation phases. The parameters are used to determine deformation phases in the software are strike/dip angle of the fault and the striation slope angle (pitch angle). In this case, strike is dip direction plus or minus $90^{\circ}$.

The location of survey sites and their coordinates on the Co To - Thanh Lan in this study are shown in the Figure 2 and Table 1.

Gasgeochemistry analyses. A «CrystalLux4000M» (Russia) gas chromatograph, equipped with a flame ionization detector (FID) and two detectors with thermal conductivity (TCD), was used for gas composition analyses of hydrocarbon gases, nitrogen, oxygen and carbon dioxide. Helium and hydrogen were analyzed using gas chromatograph «Chromatek-Gasochrom 2000» («Chromatek», Russia) with hyper sensibility detector (1-2 ppm on helium and hydrogen), and the vacuum extraction unit. Duration of the hydrocarbon gas analysis is 20 minutes, analysis of helium and hydrogen is 5 minutes. Helium and hydrogen extracted from the fresh water on the islands Co To and adjacent was made by the Head Space method. The sediments around the islands were sampled from a gravity corer using $12 \mathrm{ml}$ plastic syringes, and then transferred into $68 \mathrm{ml}$ airtight vials filled with a saturated water solution of $\mathrm{NaCl}$ containing $\mathrm{NaN}_{3}$. The sampling time interval was $10 \mathrm{~cm}$. Then the $\mathrm{NaCl}$ solution was added up to the top and vial was closed with a rubber stopper with a needle used to remove excess solution and air. Samples were fixed and stored at temperature $+4^{\circ} \mathrm{C}$ in a dark place for the subsequent gas extraction in IMGG VAST and analyze in POI FEB RAS. At determining background methane concentrations we applied methods regulated by standard instructions of background matter (gas) concentration determining

Table 1. Coordinate of geological and tectonic survey sites on Co To - Thanh Lan islands.

\begin{tabular}{cccc|c|c|c|c|c}
\hline No & Survey sites & Longitude & Latitude & No & Survey sites & Longitude & Latitude \\
\hline 01 & CT-01 & $107^{\circ} 45^{\prime} 42.69^{\prime \prime}$ & $20^{\circ} 57^{\prime} 59.10^{\prime \prime}$ & 10 & CT-09 & $107^{\circ} 46^{\prime} 40.29^{\prime \prime}$ & $20^{\circ} 58^{\prime} 24.96^{\prime \prime}$ \\
02 & CT-02 & $107^{\circ} 46^{\prime} 02.30^{\prime \prime}$ & $20^{\circ} 58^{\prime} 04.29^{\prime \prime}$ & 11 & CT-10 & $107^{\circ} 46^{\prime} 43.68^{\prime \prime}$ & $20^{\circ} 58^{\prime} 21.00^{\prime \prime}$ \\
03 & CT-03 & $107^{\circ} 44^{\prime} 36.60^{\prime \prime}$ & $21^{\circ} 00^{\prime} 06.40^{\prime \prime}$ & 12 & CT-11 & $107^{\circ} 46^{\prime} 46.92^{\prime \prime}$ & $20^{\circ} 58^{\prime} 18.12^{\prime \prime}$ \\
04 & CT-04 & $107^{\circ} 45^{\prime} 15.99^{\prime \prime}$ & $20^{\circ} 57^{\prime} 35.79^{\prime \prime}$ & 13 & CT-12 & $1^{\prime \prime} 47^{\circ} 45^{\prime} 53.64^{\prime \prime}$ & $20^{\circ} 57^{\prime} 41.40^{\prime \prime}$ \\
05 & CT-05 & $107^{\circ} 45^{\prime} 15.09^{\prime \prime}$ & $20^{\circ} 57^{\prime} 31.79^{\prime \prime}$ & 14 & Coto-05 & $1^{\prime \prime} 7^{\circ} 45^{\prime} 23.79^{\prime \prime}$ & $21^{\circ} 00^{\prime} 45.69^{\prime \prime}$ \\
06 & CT-06 & $107^{\circ} 45^{\prime} 16.09^{\prime \prime}$ & $20^{\circ} 57^{\prime} 30.60^{\prime \prime}$ & 15 & TL-01 & $107^{\circ} 48^{\prime} 21.99^{\prime \prime}$ & $20^{\circ} 59^{\prime} 29.19^{\prime \prime}$ \\
07 & CT-07 & $107^{\circ} 45^{\prime} 43.59^{\prime \prime}$ & $20^{\circ} 57^{\prime} 27.50^{\prime \prime}$ & 16 & TL-02 & $107^{\circ} 48^{\prime} 29.00^{\prime \prime}$ & $20^{\circ} 59^{\prime} 25.90^{\prime \prime}$ \\
08 & CT-08 & $107^{\circ} 46^{\prime} 58.19^{\prime \prime}$ & $20^{\circ} 59^{\prime} 26.99^{\prime \prime}$ & 17 & TL-03 & $107^{\circ} 49^{\prime} 10.09^{\prime \prime}$ & $21^{\circ} 01^{\prime} 17.19^{\prime \prime}$ \\
09 & CT-08-1 & $107^{\circ} 47^{\prime} 00.89^{\prime \prime}$ & $20^{\circ} 59^{\prime} 26.70^{\prime \prime}$ & 18 & TL-04 & $107^{\circ} 48^{\prime} 24.00^{\prime \prime}$ & $21^{\circ} 00^{\prime} 10.90^{\prime \prime}$ \\
\hline
\end{tabular}




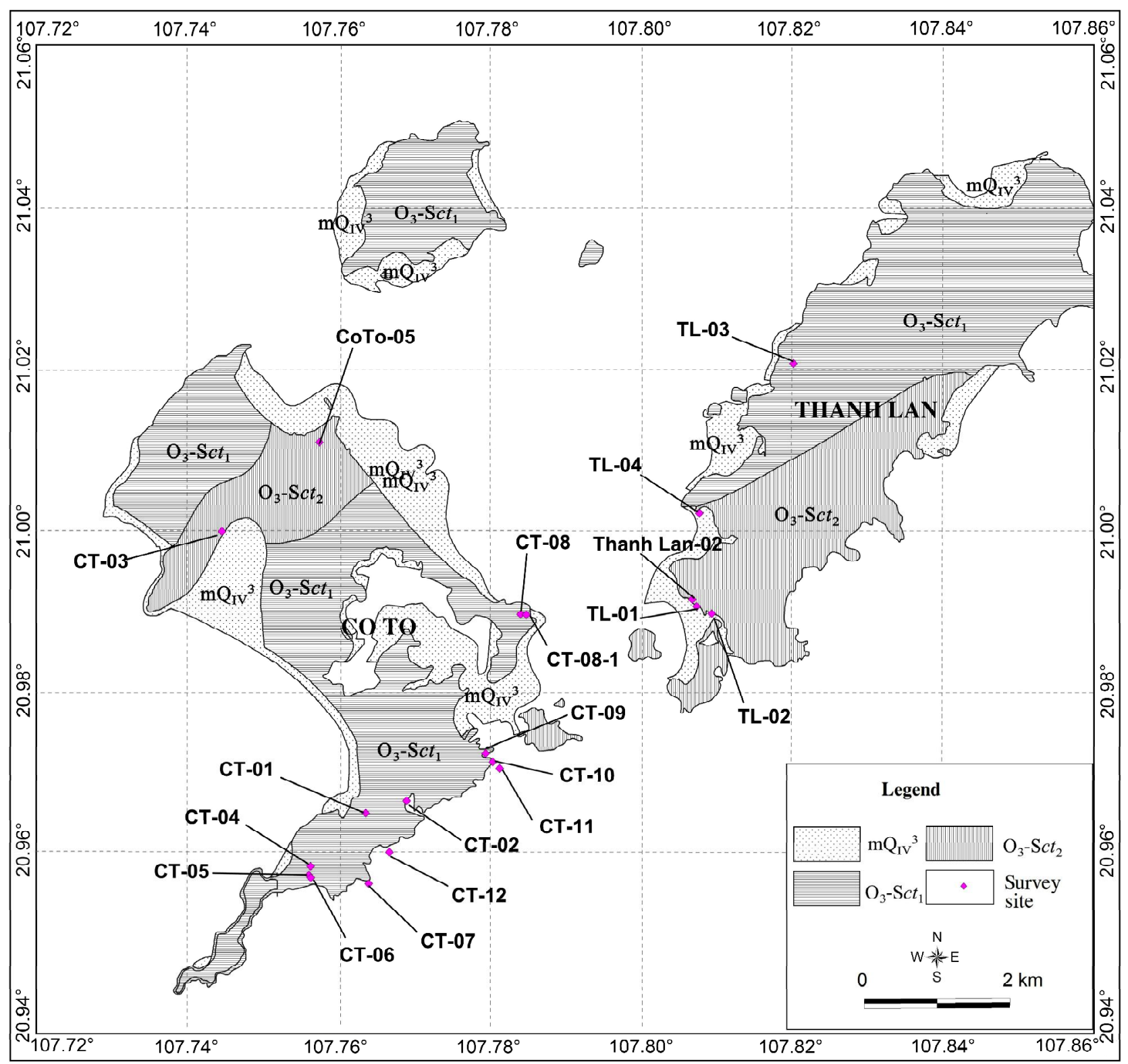

Figure 2. Location map of geological and tectonic survey sites on Co To - Thanh Lan islands.

and available methodic statistical published sources [20]. Advanced MS analyzes conducted in the Nagoya University (Prof. U. Tsunogai, Japan).

\section{RESULTS AND DISCUSSIONS}

The analytical and statistical results of striation on the fault surface, the movement of quartz veins and marked stratigraphy, which obtained at each survey site as in Figure 2 and Table 1, plotted on the lower hemisphere projection from the program Faultkin 7, clarified that, within Co To - Thanh Lan islands 04 mainly compressive phases with the directions of E-W, NE-SW, NW-SE, N-S and 02 extensive phases with the direction of NE-SW and
NW-SE existed. In particular, there are 6/18 survey sites with the compressive direction of E-W; 07/18 survey sites with the compressive direction of NE-SW; 09/18 survey sites with the compressive direction of NW-SE; 10/18 survey sites with the compressive direction of N-S; and 08/18 survey sites with the extensive and compressive direction NE-SW and NW-SE.

The evidences of the fault slip on the Co To - Thanh Lan are images demonstrated in Figures 3 and 4. The illustrated features clearly demonstrate very steep patterns of the reverse and normal faults distributed in the study area, commonly observing in the compressed tectonic environment. The amplitude of the plotted faults is not 

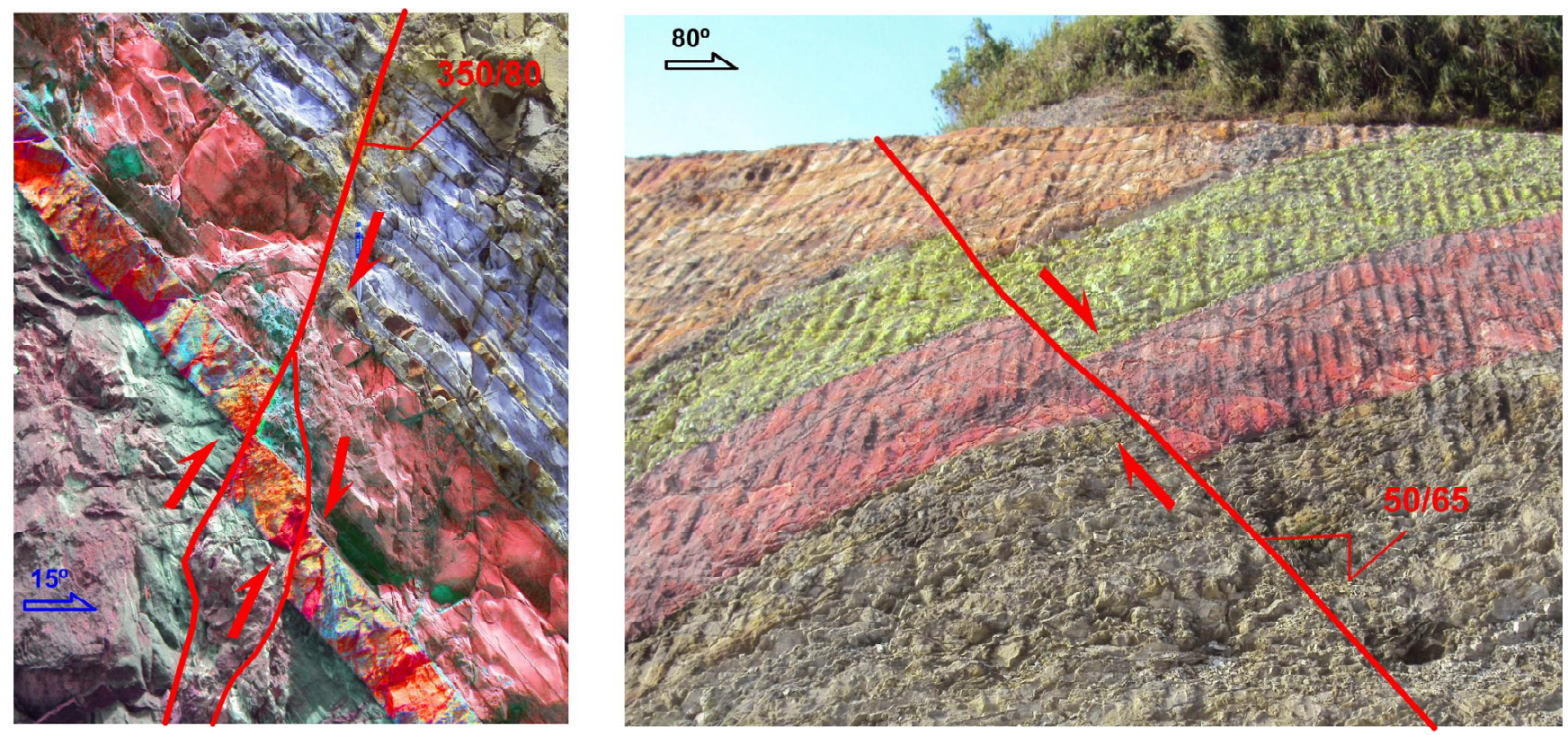

Figure 3. (a) Right movement of reverse fault (350/80o: Dip direction/Dip angle) in sedimentary rocks of Co To formation $\left(\mathrm{O}_{3}-\mathrm{S}_{2} \mathrm{ct}\right)$ with distance of $10 \mathrm{~cm}$ at survey site CT-03; (b) Right movement of normal fault (050/60: Dip direction/Dip angle) in sedimentary rock of Co To formation $\left(\mathrm{O}_{3}-\mathrm{S}_{2} \mathrm{ct}\right)$ with distance of $60 \mathrm{~cm}$ at survey site CT- 06 .

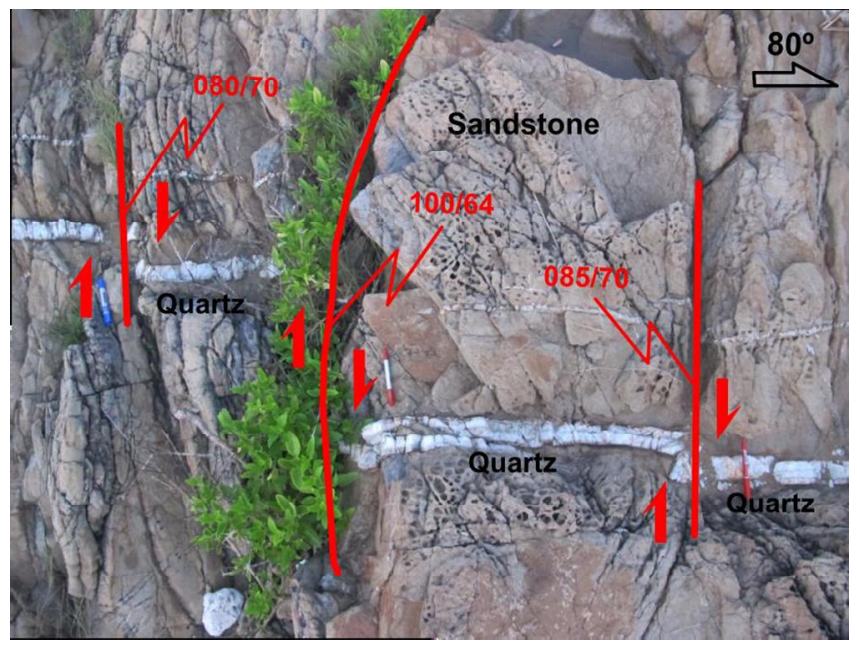

Figure 4. The evidence of right lateral strike slip N-S striking fault from movement system of quartz veins in sandstone of Co To formation $\left(\mathrm{O}_{3}-\mathrm{S}_{2} \mathrm{ct}\right)$ at site CT- 07 .

too high, rather intensively developed on many sites of the islands. These features are direct reflections from the main faults (Fig. 1) stress pattern.

Noticeably, that the numerous fracture zones expose the cracks filled by quartz, calcite and other minerals clear reflecting the position of the breaks of the sub-lateral features by the vertical displacements (Fig. 4).

Most of above compressive features caused the movement of the right and left lateral strike slip along two sides of the particular fault zone. Their stress state at each survey site is presented as in the Figure 5-9 and Table 2-6. Compressive stress state in E-W direction developed on the southeastern part of the Co-To Island within the Ordovician-Silurian complexes (Fig. 5).

Dip directions on the right lateral strike slip faults vary $135-321^{\circ}$, deep angles change in the $72-81^{\circ}$ respectively (Table 2). Even on these data, we can suppose a certain correlation between deep direction and deep angles on the observed faults. Opposite, left lateral slips do not show these interrelations. So, this feature could be a part of structural regularities in the differences between the left and right slip faulting. In further, we will trace these features on the other islands of the study area.

Compressive stress state in NE-SW direction is observed on the SE part of the Co-To Island and on the SW part of the Thanh Lan Island (also along the contact zone of Ordovician-Silurian and Quarter thicknesses, Fig. 6).

Co-existing E-W and NE-SW revealed in the SE part of the Co-To Island prove the changing in the compression axes. This could be caused by the tectonic pattern such as rotation in the certain blocks under the general RRFZ tectonic state. Deep angles of the NE-SW compressive direction are differing in general (lower) from the E-W pattern, and pitch angle of striations varies from $2^{\circ}$ to $7^{\circ}$ (Table 3 ).

Further processing of the field data lets us clarify next pattern: compressive tectonics stress state in NW- 


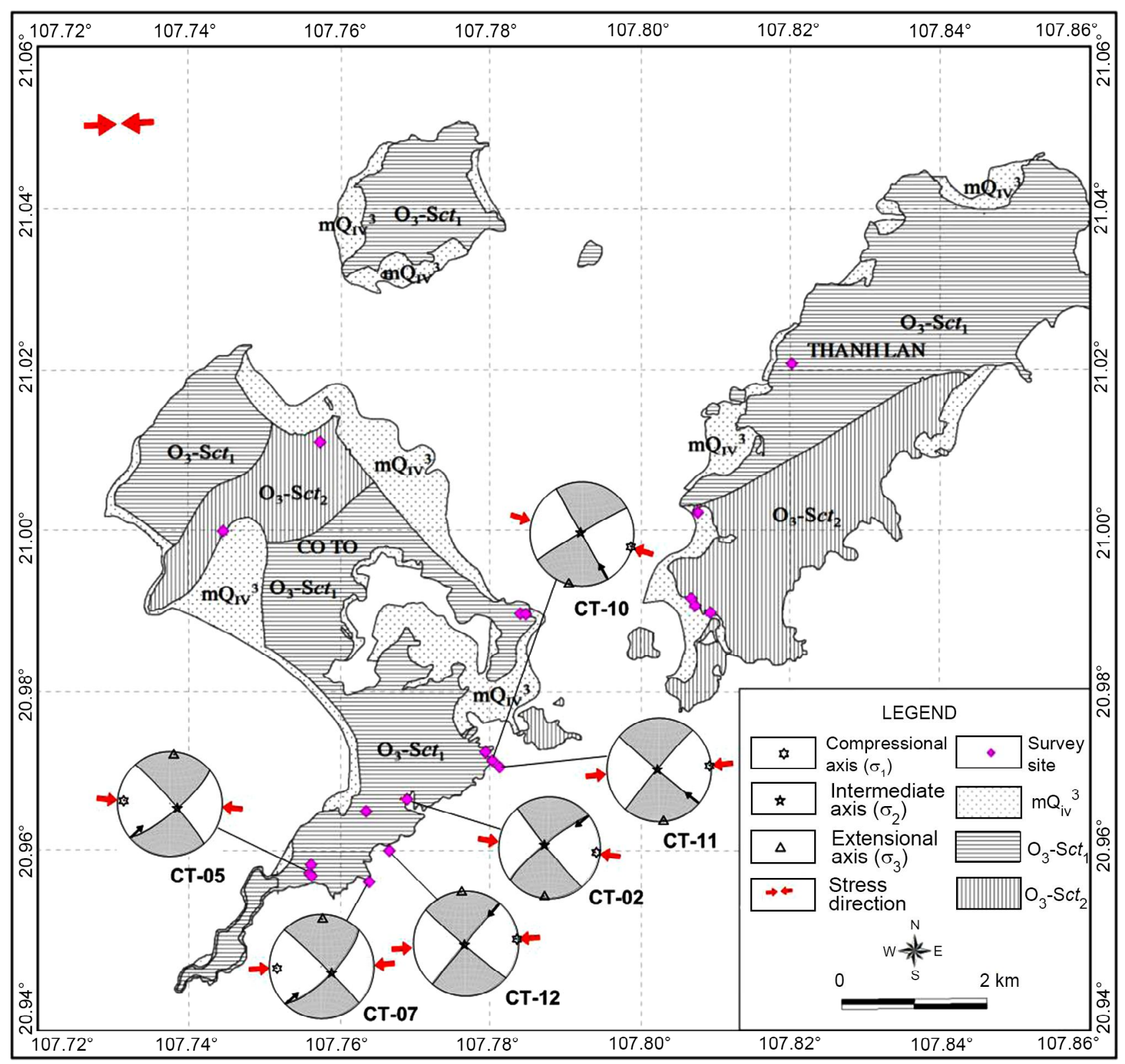

Figure 5. The map of maximum compressive stress state at each survey site in E-W direction.

Table 2. Maximum compressive stress state at each survey site in E-W direction from striation analysis.

\begin{tabular}{ccc|c|c|c|c}
\hline No & Survey site & DD/DA of fault & Sigma1, $\left(\sigma_{1}\right)$ & Sigma2, $\left(\sigma_{2}\right)$ & Sigma3, $\left(\sigma_{3}\right)$ & \multicolumn{1}{c}{ Fault descriptions } \\
\hline 1 & CT-02 & $321 / 81$ & $096 / 09$ & $302 / 80$ & $186 / 04$ & $\begin{array}{l}\text { Right lateral strike slip fault, pitch } \\
\text { angle of striation }=3^{\circ}\end{array}$ \\
2 & CT-05 & $140 / 77$ & $274 / 11$ & $127 / 76$ & $005 / 07$ & $\begin{array}{l}\text { Right lateral strike slip fault, pitch } \\
\text { angle of striation }=3^{\circ}\end{array}$ \\
3 & CT-07 & $135 / 72$ & $268 / 15$ & $124 / 72$ & $001 / 10$ & $\begin{array}{l}\text { Right lateral strike slip fault, pitch } \\
\text { angle of striation }=3^{\circ}\end{array}$ \\
4 & CT-10 & $240 / 89$ & $105 / 03$ & $318 / 87$ & $195 / 02$ & $\begin{array}{l}\text { Left lateral strike slip fault } \\
\text { Left lateral strike slip fault }\end{array}$ \\
5 & CT-11 & $220 / 89$ & $085 / 03$ & $293 / 86$ & $175 / 01$ & $\begin{array}{l}\text { Right lateral strike slip fault } \\
6\end{array}$ \\
\hline
\end{tabular}

DD/DA: Dip direction/Dip angle of fault. 


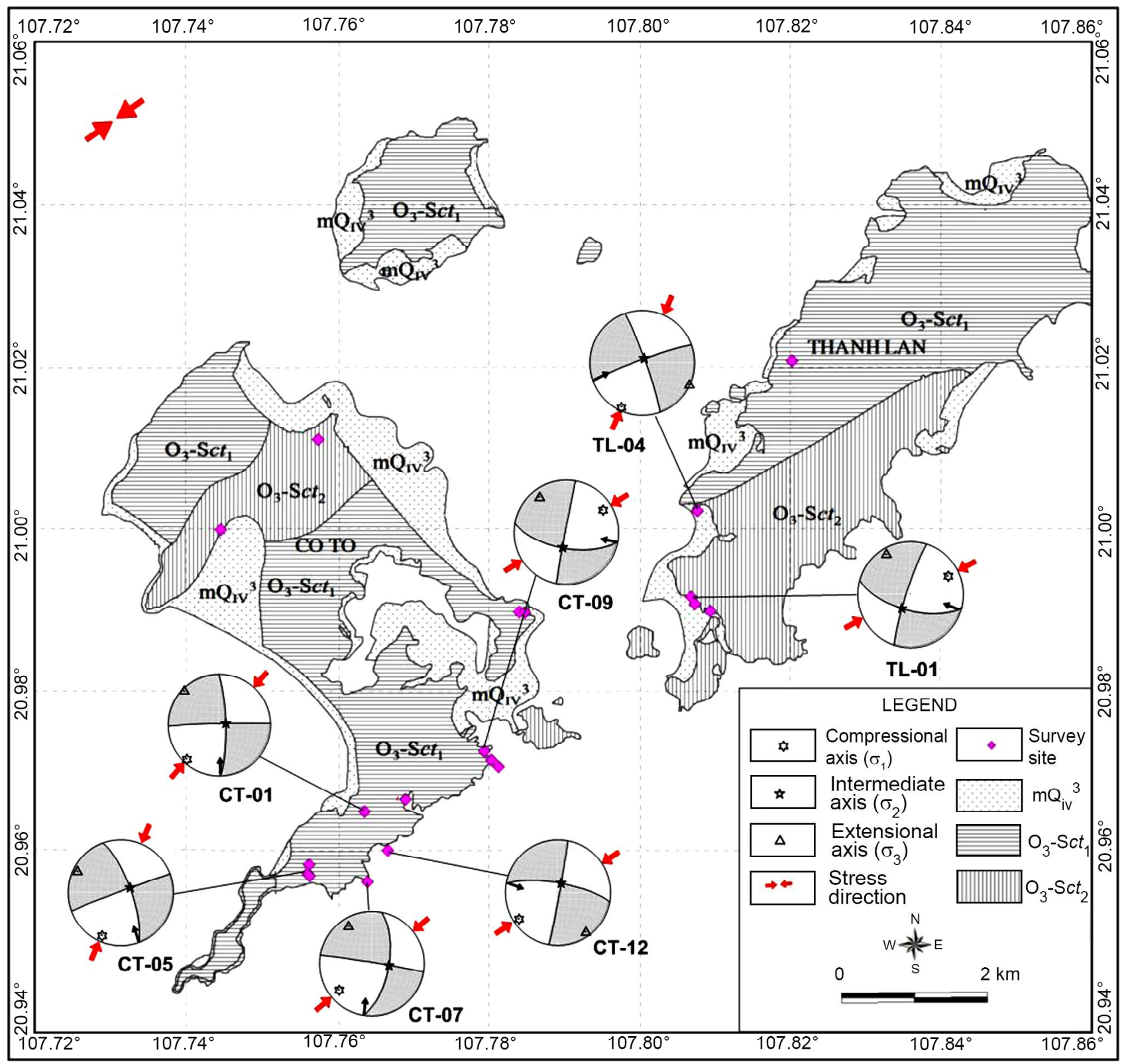

Figure 6. The map of maximum compressive stress state at each survey site in NE-SW direction.

SE direction. This pattern also supports changing in the general compressive axes reflected in the study area on 9 sites (Fig. 7) - more widely reflected on the faults pattern and striations.

This compressive mode NW-SE directed exposing the widest range of the DD/DA values as well as pitch angles of the striations $\left(2-30^{\circ}\right)$ on the left and right lateral strike slip faults. These values (Table 4) indicate some kind of the next transition tectonic sub-phase. Counterclockwise rotation mode could be discussed, but need more evidences from regional and large scale field surveys.
Compressive stress state in a sub N-S direction is most widely observed and, probably, most brightly manifested in the studied 2 Islands (Fig. 8). Dip direction and deep angles do not have any correlation, but the pitch angles of striations occupy a more narrow range of values $\left(2-7^{\circ}\right)$ than in the previous NW-SE pattern (Table 5).

Right lateral strike slip fault mostly manifested in this N-S pattern. Deep angles are characterized by the strong differences $\left(58-82^{\circ}\right)$, similar as N-S pattern $(60-$ $\left.90^{\circ}\right)$ and dip directions occupies vary in wide ranges in both patterns (Table 4, Table 5). 
Table 3. Maximum compressive stress state at each survey site in NE-SW direction from striation analysis.

\begin{tabular}{|c|c|c|c|c|c|c|}
\hline No & Survey site & $\mathrm{DD} / \mathrm{DA}$ & Sigma1, $\left(\sigma_{1}\right)$ & Sigma2, $\left(\sigma_{2}\right)$ & Sigma3, $\left(\sigma_{3}\right)$ & Fault descriptions \\
\hline 1 & CT-01 & $090 / 80$ & $224 / 08$ & $076 / 80$ & $314 / 06$ & $\begin{array}{l}\text { Right lateral strike slip fault, pitch angle of } \\
\text { striation }=2^{\circ}\end{array}$ \\
\hline 2 & CT-05 & $070 / 74$ & $204 / 12$ & $061 / 74$ & $296 / 09$ & $\begin{array}{l}\text { Right lateral strike slip fault, pitch angle of } \\
\text { striation }=2^{\circ}\end{array}$ \\
\hline 3 & CT-07 & $100 / 64$ & $231 / 19$ & 096/64 & $327 / 16$ & $\begin{array}{l}\text { Right lateral strike slip fault, pitch angle of } \\
\text { striation }=2^{\circ}\end{array}$ \\
\hline 4 & СТ-09 & $190 / 65$ & $058 / 19$ & $196 / 65$ & $323 / 16$ & $\begin{array}{l}\text { Left lateral strike slip fault, pitch angle of } \\
\text { striation }=2^{\circ}\end{array}$ \\
\hline 5 & CT-12 & $010 / 75$ & $236 / 12$ & $016 / 74$ & $145 / 10$ & $\begin{array}{l}\text { Left lateral strike slip fault, pitch angle of } \\
\text { striation }=3^{\circ}\end{array}$ \\
\hline 6 & TL-01 & $195 / 65$ & $064 / 23$ & $212 / 64$ & $329 / 12$ & $\begin{array}{l}\text { Left lateral strike slip fault, pitch angle of } \\
\text { striation }=5^{\circ}\end{array}$ \\
\hline 7 & TL-04 & $340 / 85$ & $205 / 07$ & $023 / 83$ & $115 / 02$ & $\begin{array}{l}\text { Left lateral strike slip fault, pitch angle of } \\
\text { striation }=7^{\circ}\end{array}$ \\
\hline
\end{tabular}

Table 4. Maximum compressive stress state at each survey site in NW-SE direction from striation analysis.

\begin{tabular}{|c|c|c|c|c|c|c|}
\hline No & Survey site & $\mathrm{DD} / \mathrm{DA}$ & Sigma1, $\left(\sigma_{1}\right)$ & Sigma2, $\left(\sigma_{2}\right)$ & Sigma3, $\left(\sigma_{3}\right)$ & Fault characteristics \\
\hline 1 & CT-02 & $001 / 60$ & $130 / 23$ & $355 / 60$ & $227 / 19$ & $\begin{array}{l}\text { Right lateral strike slip fault, pitch angle of } \\
\text { striation }=2^{\circ}\end{array}$ \\
\hline 2 & CT-03 & $350 / 80$ & $124 / 09$ & $337 / 80$ & $216 / 06$ & $\begin{array}{l}\text { Right lateral strike slip fault, pitch angle of } \\
\text { striation }=3^{\circ}\end{array}$ \\
\hline 3 & CT-05 & $340 / 74$ & $114 / 32$ & $276 / 56$ & 018/09 & $\begin{array}{l}\text { Right normal fault, pitch angle of striation = } \\
30^{\circ}\end{array}$ \\
\hline 4 & CT-07 & $250 / 90$ & $115 / 03$ & $311 / 88$ & 205/01 & Left lateral strike slip fault \\
\hline 5 & CT-09 & $250 / 65$ & $119 / 23$ & $270 / 64$ & $024 / 12$ & $\begin{array}{l}\text { Left lateral strike slip fault, pitch angle of } \\
\text { striation }=8^{\circ}\end{array}$ \\
\hline 6 & $\mathrm{CT}-12$ & $075 / 80$ & $301 / 08$ & $087 / 80$ & $210 / 06$ & $\begin{array}{l}\text { Left lateral strike slip fault, pitch angle of } \\
\text { striation }=2^{\circ}\end{array}$ \\
\hline 7 & TL-01 & $350 / 78$ & $124 / 10$ & $339 / 77$ & $215 / 07$ & $\begin{array}{l}\text { Right lateral strike slip fault, pitch angle of } \\
\text { striation }=2^{\circ}\end{array}$ \\
\hline 8 & TL-03 & $270 / 88$ & $134 / 02$ & $312 / 87$ & 044/01 & Left lateral strike slip fault \\
\hline 9 & TL-04 & $195 / 90$ & $320 / 03$ & $139 / 88$ & $050 / 02$ & Right lateral strike slip fault \\
\hline
\end{tabular}

The last observed feature is a complicated compressive and extensive stress states in NE-SW (extension) and NW-SE (rare extension and mostly compression) direction (Fig. 9). This probably indicates the transition reverses of the compressive-extension geotectonics modes and has to be confirmed by the paleohistorical examination.

Pitch angles of striations in this pattern show clearly the largest value among the descriptions before and plotted on figures 2-8). Right normal faults, left thrust faults, left normal faults and thrust faults mapped in this pattern reflected by the big pitch angles of striations similar to each other (Table 6).

The statistical results in Figure 5-9 showed that, most of the survey sites have more than one tectonic activity phase. Based on the relation to pair of overlap striations on the fault surface at survey sites: CT-02, CT03, CT-05 and TL-04 on the Table 7, the tectonic phases are arranged in order of (1) E-W, (2) NE-SW, (3) NW$\mathrm{SE}$ and (4) N-S. Rotation and reverse movements are the main focus of the further studies.

The order of the tectonic activity phases which obtained from analyzing field data matches well with the result of the some previous studies of the Red River Fault System, but allowed us to reveal new large scale indicators of the very specific and active faulting exposed on the Co To and Thanh Lan Islands. The first one is the tectonic activity phase with E-W compression direction which caused the left-lateral motion of Red River Fault System during Oligocene - Middle Miocene; the second one is the tectonic activity phase of NE-SW compressive direction which caused the tectonic inversion of NW- 


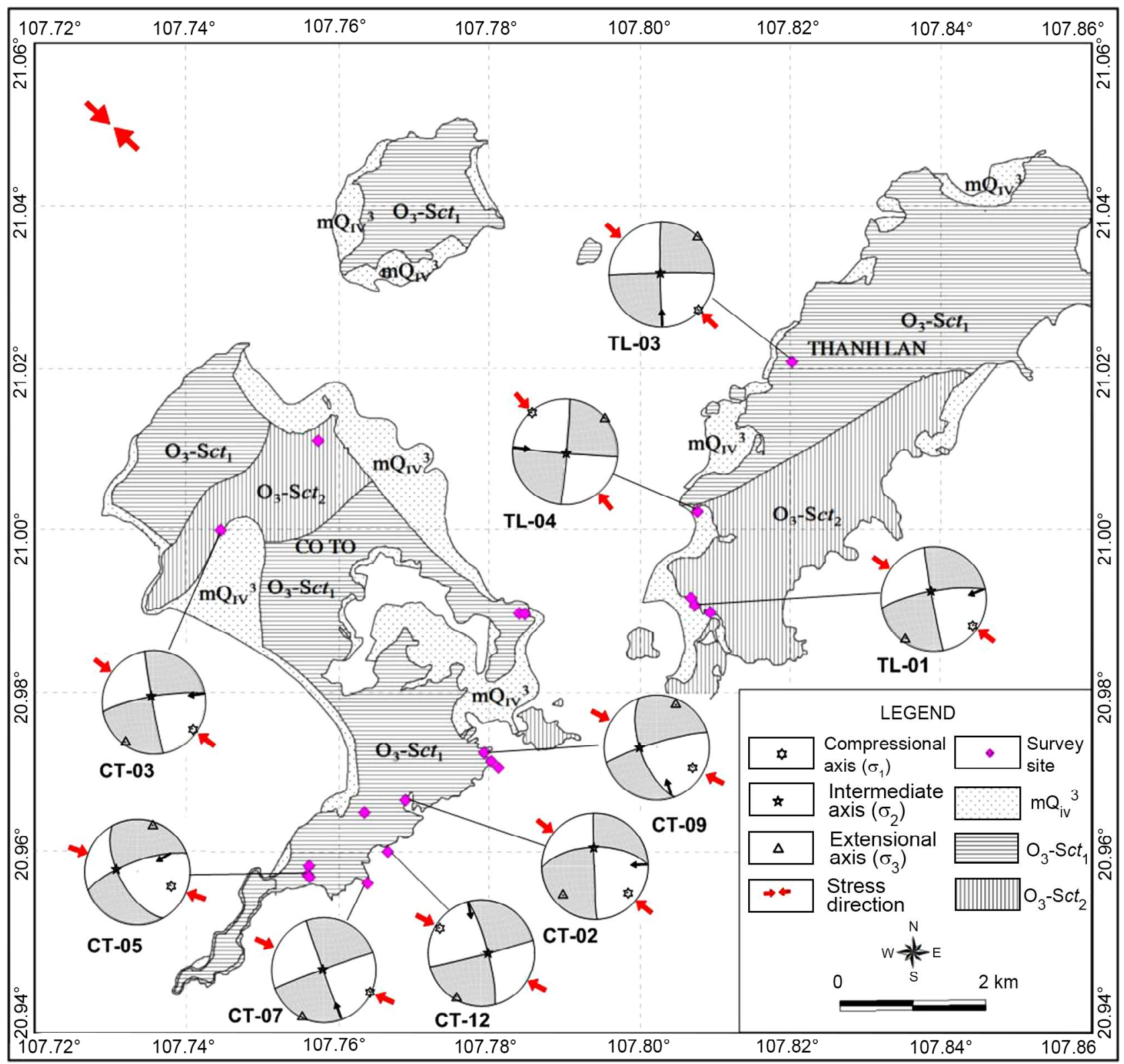

Figure 7. The map of maximum compressive stress state at each survey site in NW-SE direction.

SE trending fault in the north of Red River sedimentary basin; the third one is the tectonic activity phase of NWSE compression direction which caused right-lateral of Red River Fault System; the last one is the tectonic activity phase of N-S compression direction which caused the right-lateral motion of Red River Fault System in Pliocene-Quaternary period to present time and reflected also in the compressive and extension fracturing and faulting accompanying by the pitch angle of striation. Signs of the rotating pattern could be proposed in the Co To - Thanh Lan Islands geo-block. Such rotation could be discussed on counter clockwise direction as a result of the regional Red River Fault Zone history development. During the tectonic history the inversions of this rotating like movement could be reflected following RRFZ and adjacent geo-blocks behavior. Age and duration of the tectonic phases are still under discussion, but definitely occupies history from Oligocene up to the recent time.

In addition, some research results within the framework of cooperation between Vietnam and Russia (IMGG VAST - POI FEB RAS, 2015) in the Gulf of Tonkin area and Cat Ba, Co To, Ngoc Vung, Bach Long $\mathrm{Vi}$ islands have confirmed the existence of tectonic faults by analyzing the anomalies of methane, helium, 


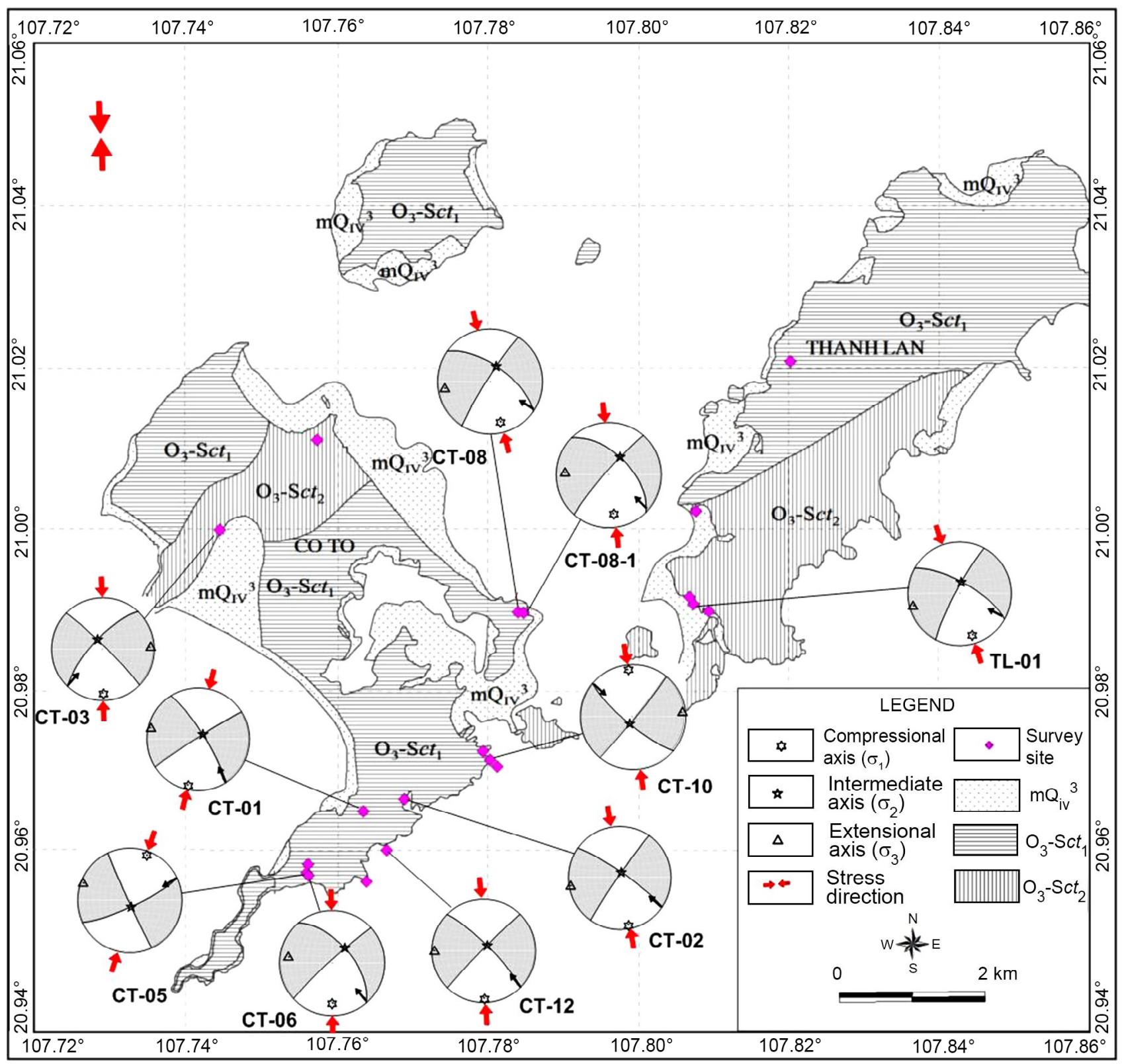

Figure 8. The map of maximum compressive stress state at each survey site in N-S direction.

hydrocarbons and carbon dioxide in water samples, soil samples and sediment samples along the fault zones $[1,2]$. The analytical results showed that the content of the elements at the survey sites within the fault zone is higher than in the surrounding areas are concentrated mainly along N-S trending faults. In particular, on the Cat Ba Island, the helium content in the water sample was up to $14.5 \mathrm{ppm}$, hydrogen was up to $25 \mathrm{ppm}$ and carbon dioxide was in the range of 18-28 ml/1; on Co To island, the helium content in water samples was up to $16 \mathrm{ppm}$, methane was up to $10.000 \mathrm{nl} / \mathrm{l}$ (very similar concentrations famous for the oil-gas accumulations).
The high permeable pathways for methane, helium and carbon dioxide injection to hosted rocks are the tectonic faults, caused anomalies. Strike slip faulting, especially in the certain sites are complicated by the sub-vertical displacements (structural junction) are the most favorable pathways for migrating gases from the interior.

The most important isotopic results are given in the Table 8. Three groups of gases are subdivided according to isotope composition of methane carbon:

1) Presumable biogenic gases with values of -70.5 $\div-93.6 \%$ o. These are typical for superficial hydrological horizons, found in the Red River mouth, and also in the 
Table 5. Maximum compressive stress state at each survey site in N-S direction from the striation analysis.

\begin{tabular}{|c|c|c|c|c|c|c|}
\hline No & Survey site & $\mathrm{DD} / \mathrm{DA}$ & Sigma1, $\left(\sigma_{1}\right)$ & $\operatorname{Sigma} 2,\left(\sigma_{2}\right)$ & $\operatorname{Sigma} 3,\left(\sigma_{3}\right)$ & Fault descriptions \\
\hline 1 & CT-01 & $058 / 80$ & $192 / 09$ & $040 / 79$ & $283 / 05$ & $\begin{array}{l}\text { Right lateral strike slip fault, pitch angle of } \\
\text { striation }=2^{\circ}\end{array}$ \\
\hline 2 & CT-02 & $035 / 82$ & $169 / 08$ & $011 / 81$ & $260 / 03$ & $\begin{array}{l}\text { Right lateral strike slip fault, pitch angle of } \\
\text { striation }=2^{\circ}\end{array}$ \\
\hline 3 & CT-03 & $313 / 73$ & $180 / 15$ & $329 / 72$ & 088/09 & $\begin{array}{l}\text { Left lateral strike slip fault, pitch angle of } \\
\text { striation }=5^{\circ}\end{array}$ \\
\hline 4 & CT-05 & $150 / 80$ & 021/08 & $166 / 80$ & $290 / 05$ & $\begin{array}{l}\text { Left lateral strike slip fault, pitch angle of } \\
\text { striation }=2^{\circ}\end{array}$ \\
\hline 5 & CT-06 & $050 / 60$ & $180 / 24$ & $039 / 59$ & $278 / 17$ & $\begin{array}{l}\text { Right lateral strike slip fault, pitch angle of } \\
\text { striation }=5^{\circ}\end{array}$ \\
\hline 6 & CT-08 & $035 / 65$ & $166 / 21$ & $021 / 65$ & $261 / 13$ & $\begin{array}{l}\text { Right lateral strike slip fault, pitch angle of } \\
\text { striation }=6^{\circ}\end{array}$ \\
\hline 7 & СТ-08-1 & $045 / 58$ & $173 / 26$ & $032 / 57$ & $273 / 17$ & $\begin{array}{l}\text { Right lateral strike slip fault, pitch angle of } \\
\text { striation }=7^{\circ}\end{array}$ \\
\hline 8 & CT-10 & $220 / 78$ & $354 / 11$ & $205 / 77$ & 085/07 & $\begin{array}{l}\text { Right lateral strike slip fault, pitch angle of } \\
\text { striation }=3^{\circ}\end{array}$ \\
\hline 9 & CT-12 & $045 / 80$ & $179 / 09$ & 028/79 & $270 / 04$ & $\begin{array}{l}\text { Right lateral strike slip fault, pitch angle of } \\
\text { striation }=3^{\circ}\end{array}$ \\
\hline 10 & TL-01 & $030 / 72$ & $163 / 17$ & 008/71 & $255 / 08$ & $\begin{array}{l}\text { Right lateral strike slip fault, pitch angle of } \\
\text { striation }=5^{\circ}\end{array}$ \\
\hline
\end{tabular}

Table 6. Maximum compressive and extensive stress state at each survey site in NE-SW and NW-SE direction from the striation analysis.

\begin{tabular}{cccc|c|c|l|l}
\hline No & Survey site & DD/DA & Sigma1, $\left(\sigma_{1}\right)$ & Sigma2, $\left(\sigma_{2}\right)$ & Sigma3, $\left(\sigma_{3}\right)$ & \multicolumn{1}{c}{ Fault descriptions } \\
\hline 1 & CT-02 & $320 / 78$ & $129 / 57$ & $232 / 08$ & $327 / 33$ & Right normal fault, pitch angle of striation $=82^{\circ}$ \\
2 & CT-03 & $225 / 65$ & $064 / 68$ & $311 / 09$ & $218 / 20$ & Left normal fault, pitch angle of striation $=80^{\circ}$ \\
3 & CT-04 & $030 / 47$ & $028 / 02$ & $118 / 03$ & $261 / 87$ & Thrust fault, pitch angle of striation $=87^{\circ}$ \\
4 & CT-05 & $160 / 80$ & $156 / 35$ & $249 / 05$ & $346 / 55$ & Left thrust fault \\
5 & CT-07 & $005 / 25$ & $170 / 22$ & $326 / 67$ & $076 / 08$ & Left thrust fault, pitch angle of striation $=70^{\circ}$ \\
6 & CT-11 & $230 / 87$ & $046 / 48$ & $140 / 04$ & $234 / 42$ & Right normal fault, pitch angle of striation $=80^{\circ}$ \\
7 & TL-01 & $330 / 42$ & $148 / 03$ & $298 / 86$ & $058 / 02$ & Thrust fault, pitch angle of striation $=85^{\circ}$ \\
8 & TL-04 & $140 / 45$ & $322 / 01$ & $052 / 02$ & $247 / 88$ & Thrust fault, pitch angle of striation $=87^{\circ}$ \\
\hline
\end{tabular}

river and lake water on the islands (e.x. Co To Isl.) of the Tonkin Gulf.

2) Mixed thermogenic and microbial gases in the sediments of the Tonkin Gulf have values $-52.2 \div$ $-58 \%$. These values, accompanied by high content of the hydrocarbon gases, pointed to mainly thermogenic origin with non-significant addition of microbial gases.

3) Mixed thermogenic and metamorphogenic gases in the hydrological wells on Cat Ba Island ranged $-25.5 \div-40.2 \%$. In this case, an obvious migratory gas inflow is observed from the folded basement of lower horizons which is defined by high methane anomalies (up to $370000 \mathrm{nl} / \mathrm{l}$ ). These indicate to the gas-condensate hydrocarbon potential.

The isotope composition of the dissolved carbon dioxide carbon both at a headspace method and at vacuum degassing demonstrates the similar values characterizing in general the carbon environment in the study area (Table 8).

Thus, anomalies of the methane, carbon dioxide and other gases, such as helium and hydrogen indicate the availability of gas permeable pathways created by the described faulting during long time history of area geological development. Not only gas channels, but dynamic-contact metamorphic processes can cause observing methane and carbon dioxide anomalies. This is a main background to continue complex tectonic and gasgeochemical study in the Northern Vietnam.

\section{CONCLUSIONS}

The analyses of over sixty striations on the fault surface and the movement of quartz veins, marked stratigraphy at 18 different survey sites on Co To - Thanh Lan islands indicated that tectonic activity in this area has 04 compressive phases of E-W, NE-SW, NW-SE and N-S 


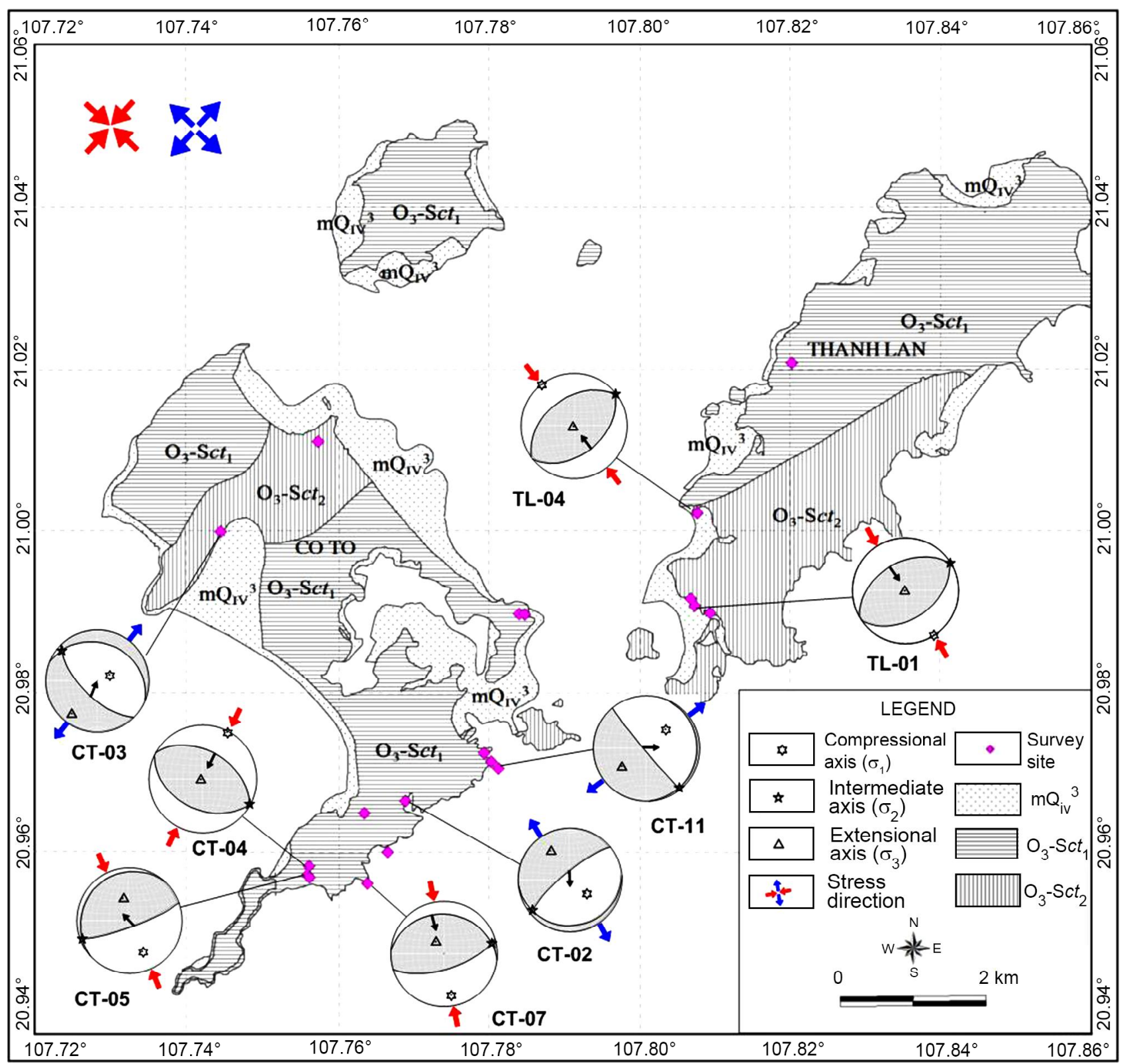

Figure 9. The map of maximum compressive and extensive stress state at each survey site in NE-SW and NW-SE direction.

direction and 02 extension phases of NE-SW and NW-SE direction which caused the tectonic inversion of NW-SE and NE-SW striking fault at survey sites of CT-04, CT-05, CT-07, TL-01 and TL-04.

Based on the generation (before and after) among overlap striations on the fault surface at survey sites of CT-02, CT-03, CT-05 and TL-04, the tectonic phases with mainly compressive direction are determined following the order of: (1) E-W, (2) NE-SW, (3) NW$\mathrm{SE}$ and (4) N-S. These results are in good correlation to some previous studies in the region, but additional new tectonic feature were revealed for the first time based on original detail field work.

Besides, the selection of the islands of the Tonkin Gulf to analyze and determine the stress state caused deformation phases is very important because they are considered as an experimental work on very clear structural manifestations and signs, including gas anomalies, exposed in the island's geological environment. The obtained results in this study propose similar further studies in the Tonkin Gulf area and adjacent area. The further study must be referred and 
Table 7. The pair of overlap striations on the same fault surface at survey sites on Co To - Thanh Lan Islands.

\begin{tabular}{|c|c|c|c|c|c|c|}
\hline No & Survey site & $\mathrm{DD} / \mathrm{DA}$ & Fault descriptions & Stress state & Stress direction & Phase order \\
\hline \multirow{2}{*}{1} & \multirow{2}{*}{ CT-02 } & $320 / 78$ & $\begin{array}{l}\text { Right normal fault, pitch angle of } \\
\text { striation }=2^{\circ}\end{array}$ & $\begin{array}{l}\text { Sig-1 }=094 / 10 \\
\text { Sig-2 }=312 / 78 \\
\text { Sig-3 }=186 / 08\end{array}$ & & Phase 1 \\
\hline & & $320 / 78$ & $\begin{array}{l}\text { Left normal fault, pitch angle of } \\
\text { striation }=20^{\circ}\end{array}$ & $\begin{array}{l}\text { Sig-1 }=186 / 23 \\
\text { Sig-2 }=020 / 67 \\
\text { Sig-3 }=278 / 05\end{array}$ & & Phase 4 \\
\hline \multirow{2}{*}{2} & \multirow{2}{*}{ CT-03 } & $250 / 80$ & $\begin{array}{l}\text { Left normal fault, pitch angle of } \\
\text { striation }=35^{\circ}\end{array}$ & $\begin{array}{l}\text { Sig-1 }=113 / 31 \\
\text { Sig-2 }=326 / 54 \\
\text { Sig-3 }=213 / 16\end{array}$ & & Phase 1 \\
\hline & & $250 / 80$ & $\begin{array}{l}\text { Left thrust fault }, \text { pitch angle of } \\
\text { striation }=60^{\circ}\end{array}$ & $\begin{array}{l}\text { Sig-1 }=226 / 28 \\
\text { Sig-2 }=335 / 29 \\
\text { Sig-3 }=101 / 46\end{array}$ & & Phase 2 \\
\hline \multirow{2}{*}{3} & \multirow{2}{*}{ CT-05 } & 070/74 & $\begin{array}{l}\text { Right normal fault, pitch angle of } \\
\text { striation }=30^{\circ}\end{array}$ & $\begin{array}{l}\text { Sig-1 }=112 / 35 \\
\text { Sig-2 }=280 / 54 \\
\text { Sig-3 }=018 / 05\end{array}$ & & Phase 1 \\
\hline & & $340 / 70$ & $\begin{array}{l}\text { Right normal fault, pitch angle of } \\
\text { striation }=2^{\circ}\end{array}$ & $\begin{array}{l}\text { Sig-1 }=204 / 12 \\
\text { Sig-2 }=061 / 74 \\
\text { Sig-3 }=296 / 10\end{array}$ & & Phase 2 \\
\hline \multirow{2}{*}{4} & \multirow{2}{*}{ TL-04 } & $340 / 85$ & $\begin{array}{l}\text { Right lateral strike slip fault, } \\
\text { pitch angle of striation }=2^{\circ}\end{array}$ & $\begin{array}{l}\text { Sig-1 }=115 / 04 \\
\text { Sig-2 }=319 / 84 \\
\text { Sig-3 }=205 / 02\end{array}$ & & Phase 3 \\
\hline & & $340 / 85$ & $\begin{array}{l}\text { Left normal fault, pitch angle of } \\
\text { striation }=50^{\circ}\end{array}$ & $\begin{array}{l}\text { Sig-1 }=195 / 37 \\
\text { Sig-2 }=066 / 40 \\
\text { Sig-3 }=308 / 29\end{array}$ & & Phase 4 \\
\hline
\end{tabular}

Table 8. The carbon dioxide and methane carbon isotope composition of the Tonkin Gulf and is coastal areas and islands (2013-2014, the MS analysis is made at Nagoya University, by the Prof. U. Tsunogai).

\begin{tabular}{|c|c|c|c|c|c|c|c|c|}
\hline № & Environment & Place & Lat & Long & $\mathrm{CH}_{4}$ & $\delta^{13} \mathrm{C} \mathrm{CH}_{4}$ & $\mathrm{CO}_{2}$ & $\delta^{13} \mathrm{C}$ \\
\hline $\begin{array}{c}\text { of } \\
\text { sample }\end{array}$ & object (sampling methode) & Name & ${ }^{\circ} \mathrm{N}$ & ${ }^{\circ} \mathrm{E}$ & $\%$ & $\%$ VPDB & $\%$ & $\%$ VPDB \\
\hline 2 & fresh water (headspace) & Co To Island & 2048.751 & 10721.377 & 0.05 & -70.5 & 1.97 & -23.3 \\
\hline 5 & fresh water (headspace) & Red River mouth & 2016.817 & 10632.233 & 5.0 & -93.6 & 1.90 & -24.2 \\
\hline $\mathrm{K}-2$ & $\begin{array}{l}\text { fresh water (vacuum } \\
\text { degassing) }\end{array}$ & $\begin{array}{l}\text { Cat Ba Island (the } \\
\text { well) }\end{array}$ & 20.7359 & 107.044 & 0.003 & -25.5 & 69.3 & -20.7 \\
\hline $\mathrm{K}-6$ & $\begin{array}{l}\text { fresh water (vacuum } \\
\text { degassing) }\end{array}$ & $\begin{array}{l}\text { Cat Ba Island (the } \\
\text { well) }\end{array}$ & 20.737 & 107.043 & 0.030 & -40.2 & 92.5 & -21.3 \\
\hline 17 & sediment (headspace ) & sediment & 2059.796 & 1088.094 & 0.0006 & -58.0 & 0.025 & n.s. \\
\hline 45 & sediment (headspace ) & sediment & 2022.464 & 10732.658 & 0.0004 & -53.2 & 0.013 & n.s. \\
\hline 71 & sediment (headspace) & sediment & 2037.65 & 10711.748 & 0.0008 & -52.2 & 0.019 & n.s. \\
\hline 79 & sediment (headspace) & sediment & 2035.514 & 1073.408 & 0.0005 & -54.3 & 0.015 & n.s. \\
\hline
\end{tabular}

compared with other adjacent areas in combination with geophysical and gas-geochemical data.

Gas-geochemistry data provide valuable information in complex with geophysical surveys for ancient and active tectonics in view of mapping, gas contents, oil and gas perspective and environmental aspects. From the other side, detail information on tectonic state helps to predict anomalies of natural gases in certain areas, and, finally, support oil-gas searching surveys. Abundance of active faults could be one of the reasons of the seismic 
activity in the study area, but this needs further research as well.

\section{ACKNOWLEDGEMENTS}

This paper is financially supported by the Project of Vietnam Academy of Science and Technology (Code: VAST05.02/15-16) and partially by the Far Eastern Branch of the Russian Academy of Sciences, Program "Far East", VAST 16-005 "Investigation of the deep fluid dynamics features and degassing processes of the lithosphere in the transition zone from continent to the Gulf of BacBo by geophysical and gasgeochemical methods". The part of research conducted by "Joint Vietnam-Russia joint laboratory for marine geosciences" (IMGG VAST - POI FEB RAS) in cooperation with Hanoi University of Natural Resources and Environment. Also research is executed with support by Grant of Russia Federation President MK-2286.2017.5.

\section{REFERENCES}

1. Akulichev V.A., Shakirov R.B., Obzhirov A.I., Phung V.P., Trung N.N., Hung D.Q., Maltseva E.V., Syrbu N.S., Polonik N.S., Anh L.D. Anomalies of Natural Gases in the Gulf of Tonkin (South China Sea). Doklady Earth Sciences. Russian Academy of Sciences. 2015. V. 461, Part 1. P. 203-207. Pleiades Publishing.

2. Anh L.D., Trung N.N., Phach Ph.V., Hung D.Q., Thanh N.T., Diep N.V., Nam B.V., Shakirov R., Obzhirov A., Iugai I., Mal'tseva E., Telegin I., Syrbu N. Characteristics of helium, methane and hydrogen distribution and their relationship with fault systems in the north of the Gulf of Tonkin. Journal of Marine Science and Technology. Vietnam Academy of Sciences and Technology (VAST). N 4. 2014. P. 78-88. DOI: 10.15625/1859-3097/14/4A/6034 In Vietnamese.

3. Cong Luong Nguyen et al. Geological and mineral resources map of Vietnam on 1:200,000. Ha Long (Hon Gai) sheet. Published and copyright by department of geology and minerals of Vietnam, HaNoi. 1999. In Vietnamese.

4. Department of Geology and Mineral of Viet Nam, Ha Noi. Geological and Mineral Resources Map of Viet Nam on 1:200.000: Ha Long (F-48-XXX). 1999. In Vietnamese.

5. Dovjicov A.E. Geology in the North Vietnam. Publishing house for science and technology, 1965. Hanoi, Vietnam. 668 p.

6. Fromaget J. Nouvelles observations sur la stratigraphie des formations primaires et secondaires du $\mathrm{N}$ de l'Indochine centrale. Bull. Soc. Géo. 1928. Fr., 4e sér., 28/1-2: pp. 85-91. Paris.

7. Fuchs E., Saladin E. Mémoire sur I'exploration des gite de combustibles et de quelques uns des gite métalliferes de l' Indochine. 1882. Ann. Des Mines, II/8: pp. 185-298. Paris.

8. Kasatkin S.A., Golozubov V. V., Phung Van Phach, Le Duc Anh, Evidences of Cenozoic Strike_Slip Dislocations of the Red River Fault System in Paleozoic Carbonate Strata of Cat Ba Island (Northern Vietnam). Russian Journal of Pacific Geology. V. 8, N 3. 2014. P. 163-176.

9. Lacassin, P., Tapponnier, H., Leloup, Ph, PhanTrong Trinh, Nguyen Trong Yem. Morphotectonic evidence for active movement along the Red River Fault System. Proceed. Inter. Seis. Haz. South. Asia. 1994. P. 66-71.

10. Michael B. W. Fyhn and Phung V. Phach. Late Neogene structural inversion around the northern Gulf of Tonkin, Vietnam: Effects from right-lateral displacement across the Red River Fault System. AGU publications. 2015. P. 290-212.

11. Nguyen Giang Vu. Structural evolution of the block 102 and 106 Song Hong basin-implication for hydrocarbon potential. Proceedings of conference on "Vietnam petroleum institute: 25 years of development and achievements". 2003. P. 284-309. In Vietnamese.

12. Nguyen Xuan Khien, Some new research results on sediments in Coto Archipelago, Quangninh. Geology and Mineral. Vietnam institute of Geoscience and mineral resources. N 7. 2000. P. 55-60.

13. Nguyen Xuan Tung and Tran Van Tri. Geological formations and Geodynamics of Vietnam. Science and Technics publishing house, Hanoi, Vietnam, 1992. 274 p. In Vietnamese.

14. Patte E. Etudes géologiques dans I' Est du Tonkin. Bull. SGI, XVI/I. 1927. $314 \mathrm{p}$.

15. Phan Trong Trinh, Ngo Van Liem, Nguyen Van Huong, Hoang Quang Vinh, Bui Van Thom, Bui Thi Thao, Mai Thanh Tan, Nguyen Hoang. Late Quaternary tectonics and seismotectonics along the Red River Fault System, North Vietnam. EarthScience Reviews 114. 2012. P. 224-235.

16. Phung Van Phach, Vu Van Chinh, Tran Van Tri, Nguyen Bieu, Phi Truong Thanh, Bui Viet Dung, Nguyen Trung Thanh. Some features of tectonics and geodynamics of Bach Long Vi Island's area (Tonkin gulf, North Viet Nam) in Cenozoic. Contributions of marine geology and Geophysics. Volume IX, Science and technology publishing house, Ha Noi. 2007. P. 7-18. In Vietnamese.

17. Pubellier M., Rangin C., Phach P. V., Que B. C., Hung D. T., Lung Sang C. L. The Cao Bang-Tien Yen Fault: implications on the relationships between the Red River Fault and the south China Coastal Belt. Adv. Nat. Sci. 4 (4). 2003. P. 347-361.

18. Rangin C., Klein M., Roques D., Le Pishon X., Trong L. V. The Red River Fault System in the Tonkin Gulf. Tectonophysics243. Vietnam. 1995. P. 209-222.

19. Shakirov R.B., Obzhirov A.I., Trung N.N., Hung D.Q., Phach Ph. V., Syrbu N.S., Mal'tseva E.V., Iugai Y.G., Polonik N.S., Anh L.D., Nam B.V., Diep N.V. Features of the natural gases distribution in the sediments and seawater in the north-west of Tonkin Gulf (South-China Sea, Vietnam). Geography and natural resources. Irkutsk, SB RAS. 2015. N 4. P. 178-188. In Russian.

20. Smirnov B.V. Probabilistic methods of forecasting in engineering geology. M: Nedra. 1983. $134 \mathrm{p}$.

21. Tapponnier P., Peltzer G., Armijo R. On the mechanics of the collision between India and Asia. In: Coward, M.P., Ries, A.C. (Eds.), Collision Tectonics. Geological Society of London, Special Publication 19. 1986. P. 115-157.

22. Vu Van Chinh. Neotectonic Development Phases and Mechanism of the Cao Bang-Tien Yen Fault. Journal of Earth Sciences. 3 (T.22). 2002. P. 181-187. In Vietnamese.

23. Tran Van Tri, Nguyen Dinh Uy, Tran Dinh Nhan, Do Tuyet. Some new research results on geological structure in Coto Archipelago. General department of geology and minerals of Vietnam. Journal of Geology Series A. N 105. 1972. P. 1-4. In Vietnamese. 
24. Witold Zuchiewicz, Nguyen Quoc Cuong, Jerzy Zasadni, Nguyen Trong Yem. Late Cenozoic tectonics of the Red River Fault System, Vietnam, in the light of geomorphic studies. Journal of Geodynamics 69. 2013. P. 11-30.

25. Zhuong le Van. New solutions of Vietnam seismicity. Thesis of the candidate of geological and mineralogical sciences:
25.00.01 / Le Van Zung. Russian University of Friendship of Peoples. Moscow, 2011. 24 p.

Recommended for publishing by G.L. Kirillova

\section{ЧонТхань Фи, Р.Б. Шакиров, Ле Дык Ань, Дук Танг Ван, Н.С. Сырбу, А.И. Обжиров \\ Особенности фаз кайнозойских деформаций на островах Кото и Тхань Лан (провинция Куанг Нинь, Тонкинский залив, Вьетнам)}

Исследование более чем шестидесяти замеров бороздчатости на сместителях разломов, смещениях кварцевых жил и стратиграфических несогласий проведены на 18 различных участках островов Кото Тхань Лан (залив Тонкин, северный Вьетнам). Результаты исследования, включающие компьютерный геоструктурный анализ, показали, что тектоническая активность района исследований имеет четыре главные фазы сжатия В-3, СВ-Ю3, С3-ЮВ, С-Ю направлений и две фазы растяжения СВ-Ю3 и С3-ЮВ направлений. Основываясь на характеристиках борозд на участках СТ-02, СТ-03, СТ-05 и TL-04 были определены тектонические фазы с преобладающими направлениями сжатия: (1) В-3, (2) CВ-Ю3, (3) С3-ЮВ, (4) С-Ю. Полученные результаты хорошо согласуются с ранее проведенными региональными исследованиями, однако позволили выявить новые геоструктурные особенности. В районе исследования были обнаружены пространственные связи между тектоническими нарушениями и аномалиями метана и его газообразных гомологов, гелия и углекислого газа. Полученные результаты позволили охарактеризовать взаимосвязь крупномасштабных и региональных геоструктурных особенностей разломной зоны рифта Красной реки. Предлагается к обсуждению возможность вращательных движений геоблоков, захватывающих острова в заливе Тонкин (северный Вьетнам). Газогеохимические аномалии подтверждают проницаемость и активность некоторых разломных зон в районе исследований.

Ключевые слова: фазы кайнозойских деформаций, сжатие, фазы растяжения, тектоника, газогеохимия, Тонкинский залив, Вьетнам. 